\title{
Role of MCM2-7 protein phosphorylation in human cancer cells
}

\author{
Liangru Fei and Hongtao $\mathrm{Xu}^{*}$
}

\begin{abstract}
A heterohexameric complex composed of minichromosome maintenance protein 2-7 (MCM2-7), which acts as a key replicative enzyme in eukaryotes, is crucial for initiating DNA synthesis only once per cell cycle. The MCM complex remains inactive through the $\mathrm{G} 1$ phase, until the $S$ phase, when it is activated to initiate replication. During the transition from the G1 to $S$ phase, the MCM undergoes multisite phosphorylation, an important change that promotes subsequent assembly of other replisome members. Phosphorylation is crucial for the regulation of MCM activity and function. MCMs can be phosphorylated by multiple kinases and these phosphorylation events are involved not only in DNA replication but also cell cycle progression and checkpoint response. Dysfunctional phosphorylation of MCMs appears to correlate with the occurrence and development of cancers. In this review, we summarize the currently available data regarding the regulatory mechanisms and functional consequences of MCM phosphorylation and seek the probability that protein kinase inhibitor can be used therapeutically to target MCM phosphorylation in cancer.
\end{abstract}

Keywords: MCM, Phosphorylation, DNA replication, Checkpoint response, Cell cycle

\section{Background}

DNA is replicated via a multi-protein machinery comprising DNA polymerase, helicase, primase, circular sliding clamps, a pentameric clamp loader, single-strand binding protein (SSB) and other components [1-5]. This machinery is often referred to as a "replisome". Initiation of DNA replication in each cell cycle is fundamental to maintain genomic integrity and stability. Key to initiation is the formation of pre-replicative complexes (pre$\mathrm{RCs}$ ) in late M/early G1 phase through the recruitment of MCM2-7 in an origin recognition complex (ORC)-, Cdc6-, and Cdt1-dependent manner [6-9]. After this key step, Dbf4-dependent kinase (DDK) and cyclin-dependent kinases (Cdks) phosphorylate MCM2-7, leading to the recruitment of Cdc45 and GINS (Go, Ichi, Ni, and San) to form the CMG (Cdc45-MCMs-GINS) replicative helicase complex. The CMG replicative helicase complex has a robust helicase activity [10-13]. In addition, emerging studies suggest that MCM2-7 plays a

\footnotetext{
*Correspondence: xuht@cmu.edu.cn

Department of Pathology, College of Basic Medical Sciences and the First Affiliated Hospital, China Medical University, No.77 Puhe Road, Shenyang North New Area, Shenyang 110122, Liaoning Province, People's Republic of China
}

critical role not only in replication, but also in transcription [14, 15], replication checkpoint [16-18], and RNA splicing [19]. As MCMs also belong to the ATPases associated with diverse cellular activities (AAA + ) family, they display ATPase activity [20]. Moreover, owing to the crucial function of MCMs, the regulatory mechanisms that modulate and control its activity are diverse and complex, particularly, the phosphorylation mechanism.

Multiple phosphorylation sites were distributed on the MCM2-7 subunits. The biological and functional consequence of MCM phosphorylation appears to be correlated with specific kinases and their phosphosites. Some MCM subunits undergo dynamic phosphorylation in a cell cycle-specific manner, which may be consistent with their cell-cycle-specific functions [21-25]. Aberrant phosphorylation of MCMs disrupts DNA replication and cell cycle progression, leading to diseases or cancers [26-31]. Several reviews have been published on MCMs. However, few specifically discuss the role of phosphorylation on MCM function. Here, we highlight the function and mechanism of MCM2-7 protein phosphorylation in human cancer cells.

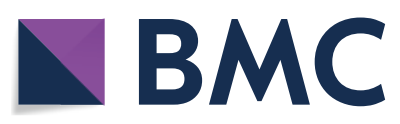

(c) The Author(s) 2018. This article is distributed under the terms of the Creative Commons Attribution 4.0 International License (http://creativecommons.org/licenses/by/4.0/), which permits unrestricted use, distribution, and reproduction in any medium, provided you give appropriate credit to the original author(s) and the source, provide a link to the Creative Commons license, and indicate if changes were made. The Creative Commons Public Domain Dedication waiver (http://creativecommons.org/ publicdomain/zero/1.0/) applies to the data made available in this article, unless otherwise stated. 


\section{Phosphorylation of MCMs by Cdc7}

Cell division cycle 7 ( $\mathrm{Cdc} 7)$ is an evolutionary conserved serine-threonine kinase that promotes the initiation of DNA replication by targeting the functional substrate MCM2-7 protein [32-35]. Similar to Cdk, Cdc7 is activated by its regulatory subunits: Dbf4 and Drf1 in human $[36,37]$. Cdc7 is found to be up-regulated in various cancers and has been characterized as an independent prognostic marker and a potential therapeutic target [38-41].

Cdc7 preferentially phosphorylates MCM2 as well as other MCM subunits (Table 1). Although there is agreement regarding specific phosphosites, each study has also identified additional sites. Differences in cell line, experimental design, or detection sensitivity may contribute to inconsistency of results among studies. In general, Cdc7 phosphorylation of MCMs is essential for the initiation of DNA replication. Tsuji et al. identified three
Cdc7-dependent MCM2 phosphosites (Ser-27/41/139), both in vivo and in vitro [21]. A triple alanine substitution at these three sites in MCM2 did not support DNA replication in HeLa cells. This suggests that Cdc7 phosphorylation of MCM2 was essential for the initiation of DNA replication. In addition, this study revealed that MCM2 accumulated on chromatin early in the G1 phase before Cdc7 phosphorylation during the G1/S phase. Phosphorylation of MCM2 did not affect the chromatin loading of MCM complex. However, another study by Chuang et al. suggested that $\mathrm{Cdc} 7$ phosphorylated MCM2 at Ser-5 prior to chromatin loading. As a result, MCM2, along with other MCM subunits accumulates with the chromatin during cell cycle re-entry [42]. However, both of the research groups concurred that $\mathrm{Cdc} 7$ phosphorylation of MCM2 had no effect on MCM complex formation $[21,42]$. The difference between studies may indicate

Table 1 Summary of MCM phosphorylation in human cancer cells

\begin{tabular}{|c|c|c|c|c|}
\hline Protein & Kinase & Phosphorylation site or domain & Biological and functional significance & References \\
\hline \multirow[t]{4}{*}{ MCM2 } & Cdc7 & S27, S41, S139 & $\begin{array}{l}\text { Suggested to be essential for initiation of DNA replication and } \\
\text { ATPase activity of MCM complex }\end{array}$ & {$[16]$} \\
\hline & Cdc7 & S5 & Promotes pre-RC assembly during cell cycle re-entry & {$[37]$} \\
\hline & Cdc7 & S40, S53, S108 & $\begin{array}{l}\text { Regulates MCM2's chromatin loading in a site-dependent man- } \\
\text { ner }\end{array}$ & {$[19]$} \\
\hline & Cdc7 & S40, S108 & Unclear & {$[43]$} \\
\hline MCM4 & Cdc7 & N-terminal & $\begin{array}{l}\text { Promotes MCM4's interaction with Cdc45 on chromatin. Sug- } \\
\text { gested to be essential for initiation of DNA replication and cell } \\
\text { growth }\end{array}$ & {$[17]$} \\
\hline MCM3 & Cdk2/CycE & $\mathrm{T} 722$ & $\begin{array}{l}\text { Promotes MCM3's chromatin loading. Regulates S phase check- } \\
\text { point activation }\end{array}$ & {$[12]$} \\
\hline \multirow[t]{2}{*}{ MCM4 } & Cdk2 & $\mathrm{S} 3, \mathrm{~T} 7, \mathrm{~S} 32, \mathrm{~S} 54, \mathrm{~T} 110$ & $\begin{array}{l}\text { Decreases chromatin loading of MCM complex to avoid re- } \\
\text { replication during mitosis }\end{array}$ & {$[45]$} \\
\hline & Cdk1, Cdk2 & $\mathrm{S} 3, \mathrm{~T} 7, \mathrm{~T} 19, \mathrm{~S} 32, \mathrm{~S} 54, \mathrm{~S} 88, \mathrm{~T} 110$ & $\begin{array}{l}\text { Inhibits chromatin loading and helicase activity of MCM } \\
\text { complex. Blocks DNA replication through inactivation of MCM } \\
\text { complex }\end{array}$ & {$[20,46-49,51]$} \\
\hline MCM7 & Cdk2/CycE, Cdk1/CycB & S121 & $\begin{array}{l}\text { Promotes MCM complex formation. Regulates S checkpoint } \\
\text { activation and mitotic exit }\end{array}$ & {$[13]$} \\
\hline \multirow[t]{2}{*}{ MCM2 } & ATR & $\mathrm{S} 108$ & Responds to replication stress and stabilizes replication forks & {$[39]$} \\
\hline & ATR & $\mathrm{S} 108$ & Responds to replication stress & {$[38]$} \\
\hline \multirow[t]{2}{*}{ MCM3 } & ATM & S535 & Responds to replication stress & {$[38]$} \\
\hline & ATM, ATR & $\mathrm{S} 728$ & Responds to replication stress & {$[58]$} \\
\hline MCM6 & ATR & S13 & Responds to replication stress & {$[59]$} \\
\hline MCM2 & SIK1 & Unclear & $\begin{array}{l}\text { Activates helicase activity of MCM complex during DNA replica- } \\
\text { tion }\end{array}$ & {$[61]$} \\
\hline MCM3 & DAPK & $\mathrm{S} 160$ & Unclear & {$[62]$} \\
\hline MCM4 & EBV-PK & $\mathrm{T} 19, \mathrm{~T} 110$ & $\begin{array}{l}\text { Blocks DNA replication through inactivation of DNA unwinding } \\
\text { by the MCM4/6/7 complex. Leads to cell growth arrest }\end{array}$ & {$[26]$} \\
\hline \multirow[t]{3}{*}{ MCM7 } & $\mathrm{p} 56^{\mathrm{Lyn}}$ & Tyr600 & $\begin{array}{l}\text { Promotes MCM complex formation, chromatin loading, DNA } \\
\text { synthesis and cancer cell proliferation. Pathologically cor- } \\
\text { relates with poor survival of breast cancer patients }\end{array}$ & {$[23]$} \\
\hline & Akt & Unclear & $\begin{array}{l}\text { Increases MCM7's chromatin loading and MCM complex forma- } \\
\text { tion. Promotes DNA replication and cancer cell proliferation }\end{array}$ & {$[24]$} \\
\hline & ILK & Unclear & Inhibits MCM7's chromatin loading and cancer cell growth & {$[25]$} \\
\hline
\end{tabular}


that biological and functional consequences of MCM2 phosphorylation by $\mathrm{Cdc} 7$ is regulated in a phosphositedependent manner. This finding is consistent with a study by Montagnoli et al. In this study, the authors demonstrated that Cdc7 phosphorylation of MCM2 isoforms showed different a affinity for chromatin, although their variable properties were similar during the cell cycle [24]. In addition, this study identified seven phosphosites in the N-terminus of MCM2 by Cdc7 (Ser-40/53/108), Cdk1/Cdk2 (Ser-13/27/41), and CK2 (Ser-139) in vitro. In cells, the MCM2 protein was phosphorylated on all of these sites. However, only Ser-40/53/108 was Cdc7dependent in vivo. In non-synchronized cells, pSer-53 MCM2 was detected both in the soluble and chromatin-enriched fractions, whereas phosphorylated MCM2 at Ser-40 and Ser-108 was only detected in the soluble fractions. However, in cells homogeneously arrested in S-phase by hydroxyurea (HU), pSer-108 and pSer-40 MCM2 were detected in chromatin-associated fractions. In addition, Ser-108 has also been reported as an ataxia-telangiectasia-mutated (ATM)/ATM- and Rad3related (ATR) kinase phosphosite on MCM2 [43, 44]. This may reflect an overlapping regulatory function between Cdc7 and ATM/ATR in replication fork machinery under replication stress. Certain studies [45-47] also confirm this phenomenon. Furthermore, Montagnoli et al. demonstrated that MCM2 phosphorylation at Ser41 (putative CDK-dependent site) and Ser-139 (putative CK2-dependent site) were not affected by reducing Cdc7 [24]. In the study by Tsuji et al., the two sites were Cdc7dependent phosphosites [21]. This may imply that multiple kinases were involved in $\mathrm{N}$-terminal phosphorylation of multiple sites in MCM2. However, results obtained from the two groups suggested that Ser-40 and Ser-108 in MCM2 were Cdc7-dependent phosphosites, both in vivo and in vitro [48]. However, functional consequences of the two phosphosites remained unclear in their study. In contrast to MCM2, phosphorylation of MCM4 remains less-studied. Masai et al. demonstrated that Cdc7-mediated N-terminal phosphorylation of MCM4 contributes to initiation of DNA replication and cell growth by promoting chromatin loading of Cdc45, a key replisome member [22]. Furthermore, N-terminal phosphorylation of MCM2, MCM4, and MCM6 might be redundant, but esssential in the initiation of DNA replication. Because the combination of MCM2, -4 , and -6N-terminal mutations resulted in the loss of cell viability, these mutations alone did not affect DNA replication or growth [22]. MCM subunits have similar function in replication regulation, but they are not identical. A recent study revealed that Cdc7/Dbf4-dependent hyperphosphorylation of MCM4, but not MCM2, correlates with replication initiation [49]. Thus, a majority of MCMs phosphosites undergo dynamic phosphorylation mediated by $\mathrm{Cdc} 7 \mathrm{in}$ a cell-cycle-specific manner. This phosphorylation pattern is consistent with the role of MCM2-7 in the initiation of DNA replication, which confirms that genomic duplication occurs once per cell cycle.

\section{Phosphorylation of MCMs by Cdk}

Cell cycle progression through each phase is tightly regulated by Cdks and their regulatory proteins, cyclins. Alterations in these proteins, lead to uncontrolled cell division, which is a characteristic of many cancers. Several lines of evidences have shown that MCMs are substrates of Cdks and some Cdk-dependent phosphosites on MCMs have been identified and characterized (Table 1). Moreover, a few phosphosites are stimulated by Cdk and Cdc7 simultaneously [22], indicating the functional crosstalk between the two classes of kinases. In general, Cdk-mediated phosphorylation of MCMs preferentially contributes to the cell cycle regulation. A study by $\mathrm{Li}$ et al. [17] revealed that $\mathrm{Cdk} 2 / \mathrm{CycE}$ phosphorylation of MCM3 Thr-722 promoted its chromatin loading. Excessive MCM3 chromatin loading activated the checkpoint pathway, which as a result blocked the $S$ phase entry, but did not affect mitotic exit. Similarly, phosphorylation of MCM7 also affects its function in cell cycle procession. In a study conducted by Wei et al. [18], it was found that both Cdk2/CycE and Cdk1/CycB phosphorylate MCM7 at Ser-121. Moreover, overexpression of the wild type (WT) MCM7, but not the MCM7-S121 mutant, resulted in an S phase block. This then activates the checkpoint kinase 1 (Chk1) checkpoint pathway through singlestranded DNA (ssDNA) accumulation in a p53-dependent manner. Phosphorylation of MCM7 at Ser-121 also contributes to the formation of MCM complex for a proper mitotic exit. Taken together, Cdk phosphorylation of MCM7 plays an important role in both activation of S phase checkpoint and regulation of proper $\mathrm{M}$ phase progression. Besides, the MCM7-S121 mutant, but not wild type MCM7, binds more efficiently to the chromatin [18]. This may indicate that the phosphorylation of MCM7 hinders its loading onto DNA. Similarly, Cdk1/2-dependent phosphorylation of MCM4 at multiple sites decreases the binding of MCM complex to DNA, avoiding re-replication during mitosis [50,51]. Therefore, phosphorylation of MCM7 at Ser-121 may also contribute to proper mitotic exit by inhibiting the MCM complex association with chromatin. Additionally, MCM4 phosphorylation not only induced the MCM complex release from chromatin, but also inactivated the complex. Previous studies indicated that MCM4 phosphorylation at specific sites leads to loss of subassembly MCM4/6/7 DNA helicase activity [52, 53], which is necessary for initiating replication $[54,55]$. Cdk-mediated phosphorylation of MCM4 
may also be a critical checkpoint in the cell cycle because MCM4 phosphorylation levels at several Cdk sites, stimulated by $\mathrm{HU}$ or ultraviolet (UV) irradiation, correlated inversely with the level of DNA synthesis to some extent [56]. In addition to Cdk, ATR-Chk1 is also involved in this phosphorylation [56]. Another study by KomamuraKohno demonstrated that some Cdk-dependent sites of MCM4 were differentially phosphorylated during the cell cycle [25], indicating MCM4 phosphorylation may have several distinct and site-specific roles. Interestingly, studies on the nuclear localization of chromatin-bound MCM4, phosphorylated at the Ser-3 and Ser-32 by Cdk2, showed that the nuclear localization was not generally colocalized with replicating DNA [25]. Similarly, Tsuji et al. have also reported that chromatin-bound Cdc7/ Dbf4 phosphorylated MCM2 did not co-localize with replication foci during G1/S and S phase [21]. One explanation for this discrepancy is that MCM helicase work at a distance from replication forks as a rotary motor that pumps DNA along its helical axis by simple rotation [57, 58].

\section{Phosphorylation of MCMs by ATM/ATR}

Replication stress, commonly known as the slowing down or stalling of replication forks, is a major source of mutations that contribute to genomic instability and tumorigenesis $[59,60]$. This threat triggers a DNA damage response (DDR). ATM and ATR, the master regulators of DDR, phosphorylate substrates to stabilize the DNA replication fork and activate cell cycle checkpoints. The checkpoint signaling pathways slow cell cycle progression, thus allowing the cell to recover and prevent inappropriate entry into mitosis [61, 62]. Several studies have suggested that ATM/ATR-dependent checkpoint pathways are directly linked to the subunits of the MCM complex (Table 1). It was suggested by Shi et al. [63] that ATM phosphorylated human MCM3 C-terminal at Ser-728, in response to DNA damage. The MCM3 phosphorylated form was preferentially localized to the nucleoplasmic fraction, and the phosphorylation did not alter its association with chromatin and other MCM subunits. One interpretation of this finding is that the chromatin-bound MCM3 C-terminal is inaccessible to ATM because of special structural changes, which may allow chromatin-bound MCM3 to escape checkpointmediated inhibition or may prevent chromatin loading of nucleoplasmic MCM3 during DNA damage [63]. ATR also contributed to MCM3 C-terminal phosphorylation in response to DNA replication stress. However, ATM still accounts for a major part of phosphorylation [63]. Therefore, ATM and ATR may contribute differently to MCM subunits phosphorylation under replication stress. Also, it has been reported that ATM phosphorylated
MCM3 at Ser-535 in response to ionizing radiation (IR) [43]. Whereas ATR phosphorylated MCM2 at Ser-108 in response to multiple forms of DNA damage and stalling of replication forks including: IR, UV light, HU, and polyamides $[43,44]$. In contrast to most ATM/ATR substrates, pSer-108 MCM2 was detected in the absence of exogenous DNA damage [43]. This corresponds with other reports on MCM2 phosphorylated at Ser-108 by Cdc7 [24, 48, 49]. In a recent study, Ser-13 at MCM6 was also reported to be a novel putative ATR target site in response to replication stress [64]. The identification of these ATM/ATR-dependent phosphosites suggests that MCM phosphorylation may be required for cells to repair DNA damage, restart replication, and recover from arrest coordinating with the checkpoint under replication stress. In concordance with this hypothesis, Izawa et al. reported that HECT and RLD domain containing E3 ubiquitin protein ligase 2 (HERC2), an E3 ligase critical for DNA damage repair pathways, regulates DNA replication progression and origin firing by facilitating MCM2 phosphorylation under replication stress [65].

\section{Phosphorylation of MCMs by other kinases}

Other than the three classes of kinases Cdc7, Cdk, and ATM/ATR, several additional kinases were also shown to be involved in MCM phosphorylation (Table 1). Among these, $\mathrm{p} 56^{\mathrm{Lyn}}$-, Akt-, and integrin-linked kinase (ILK)mediated MCM7 phosphorylation primarily correlates with the development of human cancer. MCM7 phosphorylation at Tyr-600 mediated by epidermal growth factor receptor (EGFR)-p56 ${ }^{\text {Lyn }}$-axis promotes MCM complex assembly and chromatin loading, consequently enhancing DNA synthesis and cancer cell proliferation [28]. Furthermore, the Tyr-600 phosphorylation of MCM7 correlates with poor survival of breast cancer patients [28]. Similarly, Akt-dependent phosphorylation of MCM7, mediated by receptor for activated C kinase 1 (RACK1), also facilitates association of MCM7 with chromatin and MCM complex formation. As a result, this promotes DNA replication and cell proliferation in non-small cell lung cancer [29]. In contrast to these oncogenic roles, MCM7 phosphorylation mediated by the integrin a7 (ITGA7)-ILK axis reduces MCM7 chromatin association thus inhibiting cell growth. This suggests that phosphorylation may be a critical event in the ITGA7 tumor suppression signaling pathway [30]. However, specific Akt-dependent and ILK-dependent phosphosites for MCM7 remain unclear. Phosphosites of MCM7 and the signaling pathways involved may affect the role of MCM7 phosphorylation in cancer development. In addition to MCM7, MCM2 was shown to be a substrate of salt-induciblekinase1 (SIK1) [66], MCM3 was reported to be phosphorylated by death-associated 
protein kinase (DAPK) at Ser-160 [67], and MCM4 was phosphorylated by Epstein-Barr virus-encoded protein kinase (EBV-PK) at Thr-19 and Thr-110 [31]. Among these, SIK1-dependent MCM2 phosphorylation, mediated by Sld5, is required for MCM helicase activity, but it does not affect the chromatin association of MCM2 [66]. The authors identified five SIK1-dependent phosphosites on MCM2 in vitro; however, specific phosphosites in cells need further identification. In HeLa cells, EBVPK phosphorylates MCM4 and shares at least two of the same sites (Thr-19 and Thr-110) with Cdk2. This results in the loss of MCM4/6/7 subassembly's enzyme activity, which leads to cell growth arrest [31]. In addition, most of the pThr-110 MCM4 detaches from chromatin; however, about half of pThr-19 MCM4 is bound to chromatin [31]. However, the overall chromatin-bound MCM did not change, indicating that other mechanisms may be involved. Besides, EBV-PK might also phosphorylate MCM6 and additional sites of MCM4 to block DNA replication in Epstein-Barr virus (EBV)-infected cells [31]. In contrast to the MCM2 and MCM4 phosphorylation, the consequences of DAPK-mediated MCM3 phosphorylation remains to be elucidated [67].

\section{Conclusions}

MCM proteins are regulated by multiple kinases and the consequences of these phosphorylation events reflect the critical integration of DNA replication with cell cycle and the checkpoint response (Fig. 1). However, the temporal sequence of different phosphorylation events and the precise function of phosphorylation at different sites need further investigation. Many phosphosites on MCMs identified in vitro also need further identification in cells (Table 2). Current results indicate that the MCM phosphorylation may contribute to its function by affecting MCM complex formation, chromatin binding, and (or) the helicase activity. Phosphorylation of specific sites is likely to trigger detachment of the MCM complex from chromatin. The majority of chromatin loading and phosphorylation events are regulated in a cell cycle-dependent manner. Recently, it has be found that several MCM dephosphorylation events, mediated by Rap1-interacting factor 1 (RIF1)-protein phosphatase 1 (PP1) $[49,68]$ and phosphatase and tensin homolog deleted on chromosome ten (PTEN) [69], contribute to the strict regulation of DNA replication and replisome stability. Collectively, the phosphorylation and dephosphorylation of MCM proteins regulate cell cycle progression and protect genomic stability, whereas dysfunctional phosphorylation events appear to correlate with the occurrence and development of cancers (Fig. 2). Recently, protein kinase inhibitors targeting essential cell cycle regulators or major signaling

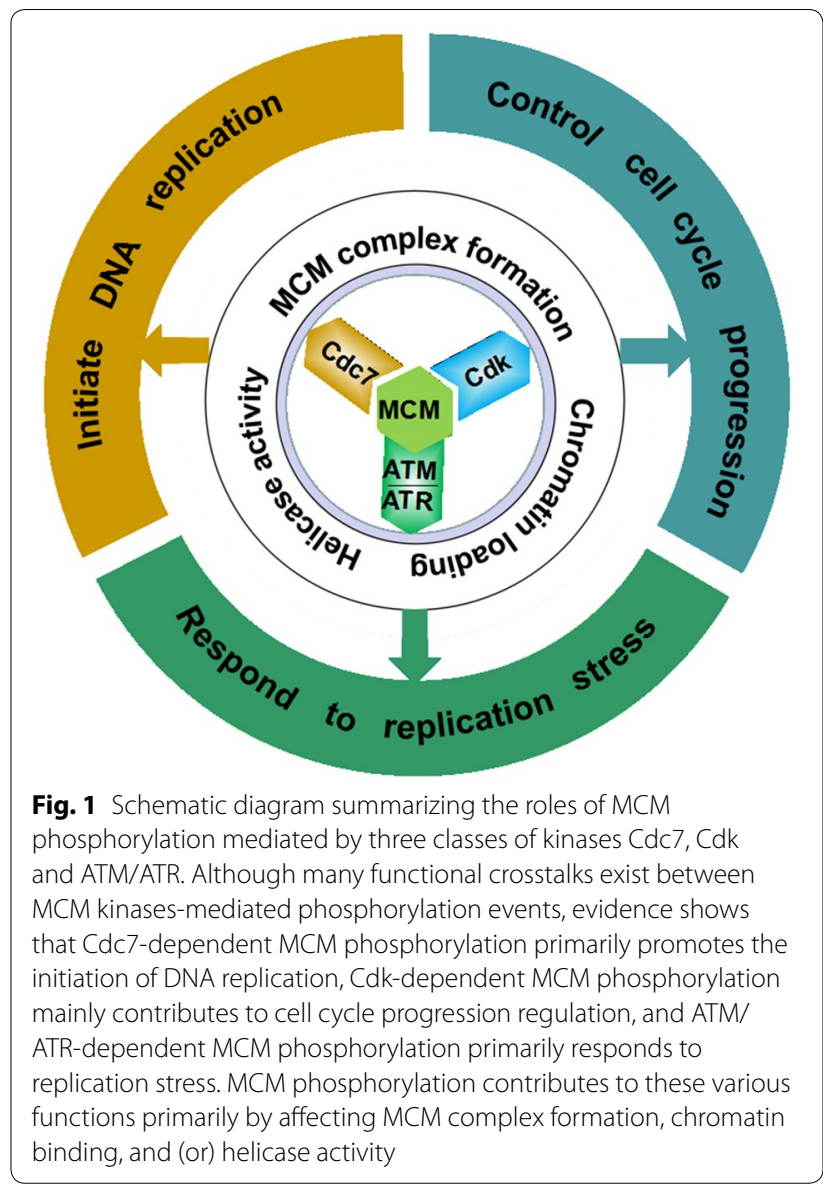

Table 2 Summary of potential phosphosites on MCMs

\begin{tabular}{|c|c|c|c|}
\hline Protein & Kinase & Phosphosite & References \\
\hline \multirow[t]{6}{*}{ MCM2 } & Cdc7 & S31, S220 & [43] \\
\hline & Cdc7 & S4, S7 & {$[37]$} \\
\hline & $\mathrm{Cdk} 2 / \mathrm{CycE} 1$ & S13, S27, S381 & [37] \\
\hline & $C d k 1, C d k 2$ & $\mathrm{~S} 13, \mathrm{~S} 27, \mathrm{~S} 41$ & [19] \\
\hline & SIK1 & S7, S27, S41, Y90, S139 & [61] \\
\hline & CK2 & S139 & [19] \\
\hline MCM4 & $\mathrm{Cdk} 2 / \mathrm{CycE} 1$ & T94 & {$[37]$} \\
\hline MCM7 & $\mathrm{Cdk} 2 / \mathrm{CycE}$ & S365 & {$[37]$} \\
\hline
\end{tabular}

pathways have become a major field of investigation for new therapeutic strategies. Drugs targeting MCM phosphorylation may be a potential method for cancer therapy. Evidence has shown that Cdc7-selective inhibitors may decrease MCM2 phosphorylation, inhibit DNA synthesis, and cancer cell viability [70-78]. Further investigation of the functional significance of MCMs phosphorylation in cancer cells is required as it may contribute to the development of novel cancer targets. 


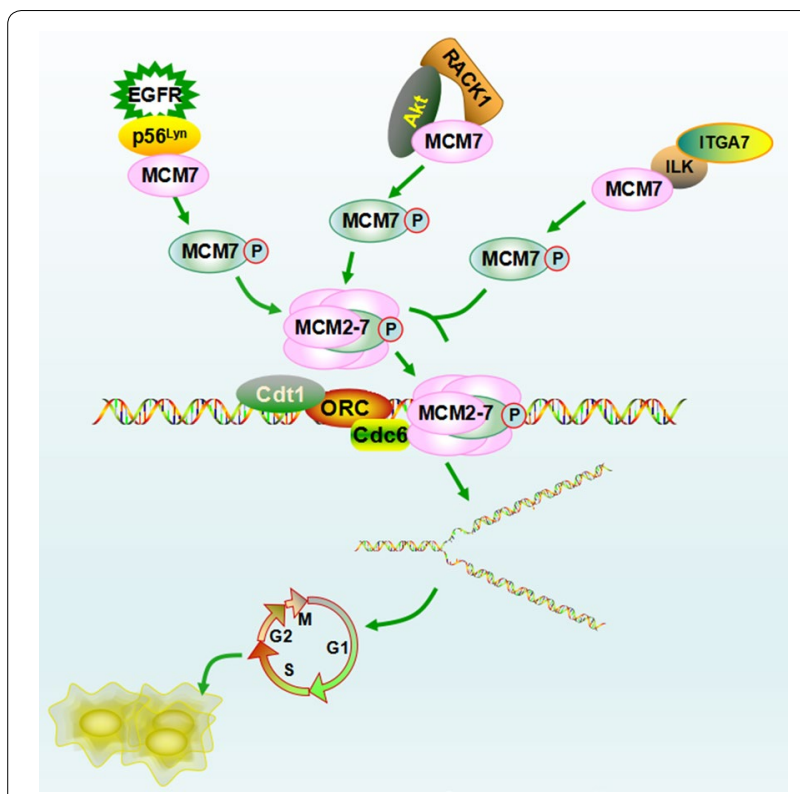

Fig. 2 Roles of MCM phosphorylation mediated by p56Lyn, Akt and ILK in cancer development. Phosphorylation of MCM7 mediated by EGFR-p56 $6^{\text {Lyn }}$ and RACK1-Akt promotes MCM complex assembly and chromatin loading, therefore enhancing DNA synthesis and cancer cell proliferation. In contrast, MCM7 phosphorylation mediated by ITGA7-ILK axis reduces MCM7 chromatin association, inhibiting cell growth

\begin{abstract}
Abbreviations
ATM: ataxia-telangiectasia-mutated kinase; ATR: ATM- and Rad3-related kinase; Cdc6: cell division cycle 6; Cdc7: cell division cycle 7; Cdc45: cell division cycle 45; Cdk: cyclin-dependent kinase; Cdt1: Cdc10 dependent transcript 1; Chk1: checkpoint kinase 1; CMG: Cdc45-MCMs-GINS; DAPK: death-associated protein kinase; DDK: Dbf4-dependent kinase; DDR: DNA damage response; EBV: Epstein-Barr virus; EBV-PK: EBV-encoded protein kinase; EGFR: epidermal growth factor receptor; GINS: Go, Ichi, Ni, and San; HERC2: HECT and RLD domain containing E3 ubiquitin protein ligase 2; HU: hydroxyurea; ILK: integrin-linked kinase; IMEs: immortalized human diploid mammary epithelials; IMFs: immortalized human fibroblasts; ITGA7: integrin a7; IR: ionizing radiation; MEFs: mouse embryo fibroblasts; NHDF: human dermal fibroblast; ORC: origin recognition complex; PP1: protein phosphatase 1; pre-RCs: pre-replicative complexes; PTEN: phosphatase and tensin homolog deleted on chromosome ten; RACK1: receptor for activated C kinase 1; RIF1: Rap1-interacting factor 1; SIK1: salt-induciblekinase1.
\end{abstract}

\section{Authors' contributions}

All authors have contributed to manuscript writing. All authors read and approved the final manuscript.

\section{Acknowledgements}

This study was supported by the National Natural Science Foundation of China (Grant No. 81372497 to H.-T. Xu) and Program for Liaoning Excellent Talents in University (Grant No. LR2015067 to H.-T. Xu). We thank Dr. Yuchen Han (China Medical University) for her kind advice and support for the manuscript.

\section{Competing interests}

The authors declare that they have no competing interests.

\section{Availability of data and materials}

Not applicable.

\section{Consent for publication}

Not applicable.

\section{Ethics approval and consent to participate}

Not applicable.

\section{Publisher's Note}

Springer Nature remains neutral with regard to jurisdictional claims in published maps and institutional affiliations.

Received: 23 May 2018 Accepted: 17 July 2018

Published online: 24 July 2018

\section{References}

1. Leman AR, Noguchi E. The replication fork: understanding the eukaryotic replication machinery and the challenges to genome duplication. GenesBasel. 2013;4:1-32.

2. Waga S, Stillman B. The DNA replication fork in eukaryotic cells. Annu Rev Biochem. 1998;67:721-51

3. Barry ER, Bell SD. DNA replication in the archaea. Microbiol Mol Biol Rev. 2006;70:876-87.

4. Garg P, Burgers PMJ. DNA polymerases that propagate the eukaryotic DNA replication fork. Crit Rev Biochem Mol. 2005:40:115-28.

5. Johnson A, O'Donnell M. Cellular DNA replicases: components and dynamics at the replication fork. Annu Rev Biochem. 2005;74:283-315.

6. Duzdevich D, Warner MD, Ticau S, Ivica NA, Bell SP, Greene EC. The dynamics of eukaryotic replication initiation: origin specificity, licensing, and firing at the single-molecule level. Mol Cell. 2015;58:483-94.

7. Bell SP, Kaguni JM. Helicase loading at chromosomal origins of replication. Csh Perspect Biol. 2013;5:a010124.

8. Evrin C, Fernandez-Cid A, Riera A, Zech J, Clarke P, Herrera MC, et al. The ORC/Cdc6/MCM2-7 complex facilitates MCM2-7 dimerization during prereplicative complex formation. Nucleic Acids Res. 2014:42:2257-69.

9. Fernandez-Cid A, Riera A, Tognetti S, Herrera MC, Samel S, Evrin C, et al. An ORC/Cdc6/MCM2-7 complex is formed in a multistep reaction to serve as a platform for MCM double-hexamer assembly. Mol Cell. 2013;50:577-88.

10. Bruck I, Dhingra N, Kaplan DL. A positive amplification mechanism involving a kinase and replication initiation factor helps assemble the replication fork helicase. J Biol Chem. 2017;292:3062-73.

11. Izumi M, Mizuno T, Yanagi K, Sugimura K, Okumura K, Imamoto N, et al. The Mcm2-7-interacting domain of human mini-chromosome maintenance $10(\mathrm{Mcm} 10)$ protein is important for stable chromatin association and origin firing. J Biol Chem. 2017;292:13008-21.

12. Yeeles JTP, Deegan TD, Janska A, Early A, Diffley JFX. Regulated eukaryotic DNA replication origin firing with purified proteins. Nature. 2015;519:431-5.

13. Bruck I, Kaplan DL. Conserved mechanism for coordinating replication fork helicase assembly with phosphorylation of the helicase. Proc Natl Acad Sci USA. 2015;112:11223-8.

14. Sheu YJ, Stillman B. The Dbf4-Cdc7 kinase promotes S phase by alleviating an inhibitory activity in Mcm4. Nature. 2010;463:113-27.

15. Snyder M, Huang $X Y$, Zhang JJ. The minichromosome maintenance proteins 2-7 (MCM2-7) are necessary for RNA polymerase II (Pol II)-mediated transcription. J Biol Chem. 2009:284:13466-72.

16. Stead BE, Brandl CJ, Sandre MK, Davey MJ. Mcm2 phosphorylation and the response to replicative stress. Bmc Genet. 2012;13:36.

17. Li JH, Deng M, Wei Q, Liu T, Tong XM, Ye X. Phosphorylation of MCM3 protein by cyclin E/Cyclin-dependent kinase 2 (Cdk2) regulates its function in cell cycle. J Biol Chem. 2011;286:39776-85.

18. Wei Q, Li JH, Liu T, Tong XM, Ye X. Phosphorylation of minichromosome maintenance protein 7 (MCM7) by cyclin/cyclin-dependent kinase affects its function in cell cycle regulation. J Biol Chem. 2013;288:19715-25.

19. Chen ZH, Yu YP, Michalopoulos G, Nelson J, Luo JH. The DNA replication licensing factor miniature chromosome maintenance 7 is essential for rna splicing of epidermal growth factor receptor, c-Met, and platelet-derived growth factor receptor. J Biol Chem. 2015;290:1404-11. 
20. Bochman ML, Schwacha A. The Mcm complex: unwinding the mechanism of a replicative helicase. Microbiol Mol Biol R. 2009;73:652-83.

21. Tsuji T, Ficarro SB, Jiang W. Essential role of phosphorylation of MCM2 by $\mathrm{Cdc7/Dbf4}$ in the initiation of DNA replication in mammalian cells. Mol Biol Cell. 2006;17:4459-72.

22. Masai H, Taniyama C, Ogino K, Matsui E, Kakusho N, Matsumoto S, et al. Phosphorylation of MCM4 by Cdc7 kinase facilitates its interaction with Cdc45 on the chromatin. J Biol Chem. 2006;281:39249-61.

23. Tan BCM, Liu HA, Lin CL, Lee SC. Functional cooperation between FACT and MCM is coordinated with cell cycle and differential complex formation. J Biomed Sci. 2010;17:11.

24. Montagnoli A, Valsasina B, Brotherton D, Troiani S, Rainoldi S, Tenca P, et al. Identification of $\mathrm{Mcm} 2$ phosphorylation sites by S-phase-regulating kinases. J Biol Chem. 2006;281:10281-90.

25. Komamura-Kohno Y, Karasawa-Shimizu K, Saitoh T, Sato M, Hanaoka F, Tanaka S, et al. Site-specific phosphorylation of MCM4 during the cell cycle in mammalian cells. FEBS J. 2006;273:1224-39.

26. Ren $X H$, Li J, Xia B, Liu W, Yang XF, Hong WX, et al. Phosphoproteomic analyses of L-02 liver cells exposed to trichloroethylene. Toxicol Mech Method. 2015;25:459-66.

27. Bonda DJ, Evans TA, Santocanale C, Llosa JC, Vina J, Bajic VP, et al. Evidence for the progression through S-phase in the ectopic cell cycle re-entry of neurons in Alzheimer disease. Aging-Us. 2009;1:382-8.

28. Huang TH, Huo LF, Wang YN, Xia WY, Wei YK, Chang SS, et al. Epidermal growth factor receptor potentiates MCM7-mediated DNA replication through tyrosine phosphorylation of Lyn kinase in human cancers. Cancer Cell. 2013;23:796-810.

29. Fei LR, Ma YN, Zhang MY, Liu XF, Luo Y, Wang CC, et al. RACK1 promotes lung cancer cell growth via an MCM7/RACK1/Akt signaling complex. Oncotarget. 2017:8:40501-13.

30. Han YC, Yu YP, Nelson J, Wu CY, Wang H, Michalopoulos GK, et al. Interaction of integrin-linked kinase and miniature chromosome maintenance 7-mediating integrin alpha 7 induced cell growth suppression. Cancer Res. 2010;70:4375-84

31. Kudoh A, Daikoku T, Ishimi Y, Kawaguchi Y, Shirata N, Iwahori S, et al. Phosphorylation of MCM4 at sites inactivating DNA helicase activity of the MCM4-MCM6-MCM7 complex during Epstein-Barr virus productive replication. J Virol. 2006;80:10064-72.

32. Deegan TD, Yeeles JTP, Diffley JFX. Phosphopeptide binding by SId 3 links Dbf4-dependent kinase to MCM replicative helicase activation. EMBO J. 2016;35:961-73.

33. Ramer MD, Suman ES, Richter $H$, Stanger $K$, Spranger M, Bieberstein $\mathrm{N}$, et al. Dbf4 and Cdc7 proteins promote DNA replication through interactions with distinct $\mathrm{Mcm} 2-7$ protein subunits. J Biol Chem. 2013;288:14926-35

34. Francis LI, Randell JCW, Takara TJ, Uchima L, Bell SP. Incorporation into the prereplicative complex activates the Mcm2-7 helicase for Cdc7-Dbf4 phosphorylation. Gene Dev. 2009;23:643-54.

35. Sheu YJ, Kinney JB, Lengronne A, Pasero P, Stillman B. Domain within the helicase subunit Mcm4 integrates multiple kinase signals to control DNA replication initiation and fork progression. Proc Natl Acad Sci USA. 2014;111:E1899-908.

36. Kitamura R, Fukatsu R, Kakusho N, Cho YS, Taniyama C, Yamazaki S, et al. Molecular mechanism of activation of human Cdc7 kinase: bipartite interaction with Dbf4/activator of S phase kinase (ASK) activation subunit stimulates ATP binding and substrate recognition. J Biol Chem. 2011;286:23031-43.

37. Yoshizawa-Sugata N, Ishii A, Taniyama C, Matsui E, Arai K, Masai H. A second human Dbf4/ASK-related protein, Drf1/ASKL1, is required for efficient progression of S and M phases. J Biol Chem. 2005;280:13062-70.

38. Li Q, Xie WF, Wang N, Li CK, Wang MD. CDC7-dependent transcriptional regulation of RAD54L is essential for tumorigenicity and radio-resistance of glioblastoma. Transl Oncol. 2018;11:300-6.

39. Melling N, Muth J, Simon R, Bokemeyer C, Terracciano L, Sauter G, et al. Cdc7 overexpression is an independent prognostic marker and a potential therapeutic target in colorectal cancer. Diagn Pathol. 2015;10:125.

40. Jaafari-Ashkavandi Z, Ashraf MJ, Abbaspoorfard AA. Overexpression of CDC7 in malignant salivary gland tumors correlates with tumor differentiation. Braz J Otorhinolaryngol. 2017. https://doi.org/10.1016/j.bjorl .2017.11.004.
41. Huggett MT, Tudzarova S, Proctor I, Loddo M, Keane MG, Stoeber K, et al. Cdc7 is a potent anti-cancer target in pancreatic cancer due to abrogation of the DNA origin activation checkpoint. Oncotarget. 2016;7:18495-507.

42. Chuang LC, Teixeira LK, Wohlschlegel JA, Henze M, Yates JR, Mendez J, et al. Phosphorylation of $\mathrm{Mcm} 2$ by Cdc7 promotes pre-replication complex assembly during cell-cycle re-entry. Mol Cell. 2009;35:206-16.

43. Cortez D, Glick G, Elledge SJ. Minichromosome maintenance proteins are direct targets of the ATM and ATR checkpoint kinases. Proc Natl Acad Sci USA. 2004;101:10078-83.

44. Martinez TF, Phillips JW, Karanja KK, Polaczek P, Wang CM, Li BC, et al. Replication stress by Py-Im polyamides induces a non-canonical ATRdependent checkpoint response. Nucleic Acids Res. 2014;42:11546-59.

45. Tudzarova S, Mulholland P, Dey A, Stoeber K, Okorokov AL, Williams GH. p53 controls CDC7 levels to reinforce $\mathrm{G} 1$ cell cycle arrest upon genotoxic stress. Cell Cycle. 2016;15:2958-72.

46. Yamada M, Watanabe K, Mistrik M, Vesela E, Protivankova I, Mailand N, et al. ATR-Chk1-APC/C-Cdh1-dependent stabilization of Cdc7-ASK (Dbf4) kinase is required for DNA lesion bypass under replication stress. Gene Dev. 2013;27:2459-72.

47. Cheng AN, Fan CC, Lo YK, Kuo CL, Wang HC, Lien IH, et al. Cdc7-Dbf4mediated phosphorylation of HSP90-S164 stabilizes HSP90-HCLK2-MRN complex to enhance ATR/ATM signaling that overcomes replication stress in cancer. Sci Rep-Uk. 2017;7:17024.

48. Charych DH, Coyne M, Yabannavar A, Narberes J, Chow S, Wallroth M, et al. Inhibition of Cdc7/Dbf4 kinase activity affects specific phosphorylation sites on MCM2 in cancer cells. J Cell Biochem. 2008;104:1075-86.

49. Alver RC, Chadha GS, Gillespie PJ, Blow JJ. Reversal of DDK-mediated MCM phosphorylation by Rif1-PP1 regulates replication initiation and replisome stability independently of ATR/Chk1. Cell Rep. 2017;18:2508-20.

50. Zhu YH, Ishimi Y, Tanudji M, Lees E. Human CDK2 inhibition modifies the dynamics of chromatin-bound minichromosome maintenance complex and replication protein A. Cell Cycle. 2005;4:1254-63.

51. Moritani M, Ishimi Y. Inhibition of DNA binding of MCM2-7 complex by phosphorylation with cyclin-dependent kinases. J Biochem. 2013;154:363-72.

52. Ishimi Y, Komamura-Kohno Y, You ZY, Omori A, Kitagawa M. Inhibition of $\mathrm{Mcm} 4,6,7$ helicase activity by phosphorylation with cyclin A/Cdk2. J Biol Chem. 2000;275:16235-41.

53. Ishimi Y, Komamura-Kohno Y. Phosphorylation of Mcm4 at specific sites by cyclin-dependent kinase leads to loss of Mcm 4,6,7 helicase activity. J Biol Chem. 2001;276:34428-33.

54. Ishimi Y. A DNA helicase activity is associated with an MCM4, -6 , and -7 protein complex. J Biol Chem. 1997;272:24508-13.

55. Lee JK, Hurwitz J. Processive DNA helicase activity of the minichromosome maintenance proteins 4, 6, and 7 complex requires forked DMA structures. Proc Natl Acad Sci USA. 2001;98:54-9.

56. Ishimi Y, Komamura-Kohno Y, Karasawa-Shimizu K, Yamada K. Levels of MCM4 phosphorylation and DNA synthesis in DNA replication block checkpoint control. J Struct Biol. 2004;146:234-41.

57. Sakakibara N, Kelman LM, Kelman Z. Unwinding the structure and function of the archaeal MCM helicase. Mol Microbiol. 2009;72:286-96.

58. Laskey RA, Madine MA. A rotary pumping model for helicase function of MCM proteins at a distance from replication forks. EMBO Rep. 2003;4:26-30

59. Kitao H, limori M, Kataoka Y, Wakasa T, Tokunaga E, Saeki H, et al. DNA replication stress and cancer chemotherapy. Cancer Sci. 2018;109:264-71.

60. Tubbs A, Nussenzweig A. Endogenous DNA damage as a source of genomic instability in cancer. Cell. 2017;168:644-56.

61. Iyer DR, Rhind N. The intra-S checkpoint responses to DNA damage. Genes-Basel. 2017:8:74

62. Chaudhury I, Koepp DM. Recovery from the DNA replication checkpoint. Genes (Basel). 2016;7:94.

63. Shi YL, Dodson GE, Mukhopadhyay PS, Shanware NP, Trinh AT, Tibbetts RS. Identification of carboxyl-terminal MCM3 phosphorylation sites using polyreactive phosphospecific antibodies. J Biol Chem. 2007;282:9236-43.

64. Wagner SA, Oehler H, Voigt A, Dalic D, Freiwald A, Serve H, et al. ATR inhibition rewires cellular signaling networks induced by replication stress. Proteomics. 2016;16:402-16. 
65. Izawa N, Wu WW, Sato K, Nishikawa H, Kato A, Boku N, et al. HERC2 interacts with claspin and regulates DNA origin firing and replication fork progression. Cancer Res. 2011:71:5621-5.

66. Joshi K, Shah VJ, Maddika S. GINS complex protein SId5 recruits SIK1 to activate MCM helicase during DNA replication. Cell Signal. 2016;28:1852-62

67. Bialik S, Berissi H, Kimchi A. A high throughput proteomics screen identifies novel substrates of death-associated protein kinase. Mol Cell Proteomics. 2008:7:1089-98.

68. Hiraga S, Ly T, Garzon J, Horejsi Z, Ohkubo Y, Endo A, et al. Human RIF1 and protein phosphatase 1 stimulate DNA replication origin licensing but suppress origin activation. EMBO Rep. 2017;18:403-19.

69. Feng JW, Liang J, Li JJ, Li YQ, Liang H, Zhao XY, et al. PTEN controls the DNA replication process through $\mathrm{MCM} 2$ in response to replicative stress. Cell Rep. 2015;13:1295-303.

70. Erbayraktar Z, Alural B, Erbayraktar RS, Erkan EP. Cell division cycle 7-kinase inhibitor PHA-767491 hydrochloride suppresses glioblastoma growth and invasiveness. Cancer Cell Int. 2016;16:88.

71. Li W, Zhao XL, Shang SQ, Shen HQ, Chen X. Dual inhibition of Cdc7 and Cdk9 by PHA-767491 suppresses hepatocarcinoma synergistically with 5-fluorouracil. Curr Cancer Drug Tar. 2015;15:196-204.

72. Kurasawa O, Homma M, Oguro Y, Miyazaki T, Mori K, Uchiyama N, et al. 2-Aminomethylthieno[3,2-d]pyrimidin-4(3H)-ones bearing 3-methylpyrazole hinge binding moiety: highly potent, selective, and time-dependent inhibitors of Cdc7 kinase. Bioorgan Med Chem. 2017:25:3658-70

73. FitzGerald J, Murillo LS, O'Brien G, O'Connell E, O'Connor A, Wu K, et al. A high through-put screen for small molecules modulating MCM2 phosphorylation identifies ryuvidine as an inducer of the DNA damage response. PLoS ONE. 2014:9:e98891.

74. Koltun ES, Tsuhako AL, Brown DS, Aay N, Arcalas A, Chan V, et al. Discovery of XL413, a potent and selective CDC7 inhibitor. Bioorg Med Chem Lett. 2012;22:3727-31.

75. Reichelt A, Bailis JM, Bartberger MD, Yao GM, Shu H, Kaller MR, et al. Synthesis and structure-activity relationship of trisubstituted thiazoles as Cdc7 kinase inhibitors. Eur J Med Chem. 2014;80:364-82

76. Irie T, Asami T, Sawa A, Uno Y, Hanada M, Taniyama C, et al. Discovery of novel furanone derivatives as potent Cdc7 kinase inhibitors. Eur J Med Chem. 2017:130:406-18.

77. Natoni A, Coyne MR, Jacobsen A, Rainey MD, O'Brien G, Healy S, et al. Characterization of a dual CDC7/CDK9 inhibitor in multiple myeloma cellular models. Cancers (Basel). 2013;5:901-18.

78. Sasi NK, Tiwari K, Soon FF, Bonte D, Wang T, Melcher K, et al. The potent Cdc7-Dbf4 (DDK) kinase inhibitor XL413 has limited activity in many cancer cell lines and discovery of potential new DDK inhibitor scaffolds. PLoS ONE. 2014;9:e113300.
Ready to submit your research? Choose BMC and benefit from

- fast, convenient online submission

- thorough peer review by experienced researchers in your field

- rapid publication on acceptance

- support for research data, including large and complex data types

- gold Open Access which fosters wider collaboration and increased citations

- maximum visibility for your research: over $100 \mathrm{M}$ website views per year

At $\mathrm{BMC}$, research is always in progress.

Learn more biomedcentral.com/submissions 